\title{
Study of Genetic Variability, Heritability and Genetic Advance in Foxtail Millet in both Rainy and Post Rainy Season.
}

\author{
Brunda S. M, Kamatar M.Y, Naveenkumar K.L and Ramaling Hundekar \\ Department of Genetics and Plant Breeding and University of Agricultural Sciences, Dharwad-5800 05
}

\begin{abstract}
An investigation was carried out to assess nature and magnitude of genetic variability for productivity related traits in foxtail millet germplasm collections during rainy and post rainy season. The analysis of variance revealed the presence of highly significant differences for all characters, indicating collections under study were genetically diverse for all the traits. Significant variation was recorded among the genotypes for various yield and yield contributing traits studied. In both the seasons high values for phenotypic coefficient $(P C V)$ and genotypic coefficient $(G C V)$ was recorded for number of tillers per plant, followed by panicle weight per plant, straw weight and grain yield per plant. Moderate GCV and PCV for characters viz., days to flowering and panicle length. The low GCV and PCV was recorded in days to maturity and plant height.The grain yield and its components viz., days to flowering, number of productive tillers, panicle length, test weight, grain yield per plant and straw yield per plant exhibited high genetic advance as per cent of mean coupled with high estimates of $h_{b}^{2}$ indicating that, the variations are attributable to high level of heritable variation and selection would be effective for improvement of these traits.
\end{abstract}

Key words: Foxtail millet, variability, heritability and genetic advance

\section{Introduction}

Foxtail millet is important minor millet belonging to the family poaceae. It is suited to conditions of low and moderate rainfall area due to early maturity period. Besides India, it is also grown in China, Russia, Japan, USA, other African and East Asian countries. In India, the cultivation of foxtail millet is confined to Andhra Pradesh, Karnataka, and Tamil Nadu. The potentiality of foxtail millet is not yet exploited properly in India. The yield levels in China is $11 \mathrm{t} / \mathrm{ha}$, whereas in India it is just ranging between 0.4-0.8t/ha suggesting a greater scope for exploitation of this millet under Indian conditions (Jiayju, 1996). The study of growth analysis would help in understanding contributions of various growth processes in accumulation of dry matter and yield. The low yield in foxtail millet is generally attributed to genetic, physiological and agronomic factors. All the factors influencing growth and development of crop plants are to be integrated at an optimum level for maximum production potential. The present investigation was carried out to find out the variation in morphophysiological and their relationship with the productivity in foxtail millet genotypes. There is wide genetic diversity available in foxtail millet, and characterizing these resources is a prerequisite for the genetic improvement of its cultivars. In this article characterization of germplasm is done.

\section{Materials and Methods}

Eleven yield contributing characteristics were taken to assess the magnitude of variability and heritability of 78 genotypes of Foxtail millet. The study was conducted at Agricultural Research Station Nipani, University of Agricultural Sciences, Dharwad during rainy season 2013 and post rainy season 2014 under both rainfed and irrigated situation respectively. The experiment was laid in a randomized block design (RBD) with three replications. Standard crop production and protection practices were followed to raise a healthy crop. Five plants were randomly selected for recording data on 11 characters viz; days to flowering, days to maturity, plant height, number of productive tillers per plant, panicle length, panicle breadth, panicle weight, grain yield per plant, grain yield per plot ,test weight and straw weight.

The data were subjected to statistical analysis. Phenotypic and genotypic variances were estimated according to the formula given by Lush (1940), PCV and GCV were computed based on the method given by Burton (1952). The heritability was computed based on the methods given according to the formula given by Johnson et al. (1955).The mean data of five plants over three replications were used for statistical analysis.

\section{Genetic variability, Heritability and Genetic advance}

\section{Results and Discussion}

ANOVA table shows highly significant differences among the genotypes were observed for all the characters indicating presence of sufficient amount of variability in both the seasons. Analysis of variance may not reveal the absolute variability and this could be accessed through standardizing the phenotypic and genotypic variances by obtaining the coefficients of variability. Hence, the components of variation such as 
genotypic coefficients of variation (GCV) and phenotypic coefficients of variation (PCV) were computed. Further it is essential for selection to separate out the environmental influence from the total variability. This indicates the accuracy with which a genotype can be identified by its phenotypic performance. The estimates of heritability alone fail to indicate the response to selection. Therefore, the heritability estimates appeared to be more meaningful when accompanied by estimates of genetic advance. Hence the genetic advances as per cent mean (GAM) was also estimated.

One of the way in which variability is assessed through a simple approach of examining range values. Wide range of variation provides an ample scope for selection of superior and desired genotypes by the plant breeders for further improvement of these characters. The phenotypic coefficient of variation (PCV) was higher than genotypic coefficient of variation (GCV) for all the traits under study.

In the present study foxtail millet genotypes exhibited high PCV and GCV for the most important economic traits viz., grain yield per plant, grain yield per plot and straw weight per plant in both the seasons. GCV describes inheritance of genetic variation. It also indicates the lower environmental influence on the expression of these characters and hence, these characters can be relied upon for selection. The values of PCV varied from 8.25 to 23.23 and 6.69 to 23.86 in rainy and post rainy season respectively. This shows that major portion of PCV was contributed by GCV this suggests that observed variation due to the genetic factors, provides the higher scope for improvement.

The moderate phenotypic co-efficient of variation and genotypic co efficient of variation were observed for characters viz., days to flowering, number of tillers, panicle length, panicle weight and test weight. These results are in consonance with earlier reports where in, moderate GCV and PCV for characters viz., days to flowering, number of tillers, panicle length and test weight in both rainy and post rainy season as reported by Sandhu et al. (1974), Nagarajan and Prasad (1980), Chidambaram and Palanisamy (1995), Nirmalakumari and Vetriventhan (2010) and Prasanna et al.(2013).This indicates the existence of comparatively moderate variability for these traits, which could be exploited for improvement through selection in advanced generations.

In both the seasons the moderate GCV and PCV for panicle weight were also reported by Chidambaram and Palanisamy (1995), Reddy and Reddy (2012) and Prasanna et al. (2013).The magnitude was moderate for the trait panicle weight. Hence there is a need for conscious selection by the plant breeder towards high grain yield.

On the whole, co efficient of variation indicated moderate amount of variability for most of the traits expect days to maturity, plant height and panicle breadth which had the low values The close correspondence between the estimates of GCV and PCV for most of the traits indicated the lesser environmental influence on the expression of these traits, which is also reflected by their high heritability values.

Heritability is a quantitative measure which provides information about the correspondence between genotypic variance and phenotypic variance, i.e., the ratio of variance due to heritable differences $\left(\sigma^{2} g\right)$ to the total phenotypic variance $\left(\sigma^{2} \mathrm{p}\right)$ and expressed as per cent. Genetic coefficient of variation alone would not indicate proportion of total heritable variation. However, the heritability estimates are better indicators of heritable portion of the variation. The broad sense heritability percentage includes the contribution of additive gene effects, allelic interactions due to dominance and non allelic due to epistasis. Genetic advance provides knowledge about expected genetic gain for particular trait after selection.

Moderate to high heritability coupled with higher magnitude of expected genetic advance for a particular trait indicates the additive gene action. On the contrary higher heritability coupled with low genetic advance is observed for any given trait, indicates the presence of non additive gene.

In the present study, most of the traits viz., days to flowering, Days to maturity, number of productive tillers per plant, panicle length, panicle breadth, test weight, grain yield per plant, straw yield per plant, showed the high estimates of broad sense heritability $\left(\mathrm{h}^{2}{ }_{\mathrm{b}}\right)$ indicating the reliability of the estimates for variation between genotypes and effectiveness of selection. In Populations which are genetically more uniform are expected to show lower heritability than the genetically variable population. Also, much variable environmental condition reduces the magnitude of heritability and much uniform environmental condition increases it (Dabholkar, 1999). Hence, as the study was conducted in the uniform environment high heritability of these traits in this study may be due to highly variable and genetically diverse accessions.

Since heritability is also influenced by environment, the information on heritability alone may not help in identifying the characters enforcing selection. Nevertheless, the heritability estimates in conjunction with the predicted genetic gain much reliable (Johnson et al., 1955). Heritability provides the information on the magnitude of inheritance of quantitative traits, while genetic advance helps in formulating suitable selection procedures.

The grain yield and its components viz., days to flowering, number of productive tillers, panicle length, test weight, grain yield per plant, straw yield per plant exhibited high genetic advance as per cent of mean coupled with high estimates of $\mathrm{h}_{\mathrm{b}}^{2}$ indicating that, the variations are attributable to high level of heritable variation and selection would be effective for improvement of these traits. The high estimates of heritability 
coupled with high genetic advance as per cent of mean are reported in the earlier studies in foxtail millet for days to flowering (Nirmalakumari and Vetriventhan, 2010; Nirmalakumari et al., 2008) number of productive tillers per plant (Islam et al, 1990), panicle length (Nirmalakumari and Vetriventhan, 2010; Lakshmanan and Guggeri, 2001), test weight (Nirmalakumari and Vetriventhan, 2010; Selvarani and Gomathinayagam, 2000b, Cill and Randhawa, 1975), grain yield (Nirmalakumari and Vetriventhan, 2010, Nirmalakumari et al., 2008,Lakshmanan and Guggeri, 2001, Selvarani and Gomathinayagam, 2000b). Days to maturity exhibited high heritability and low genetic advance this indicates the presence of non additive gene action for days to maturity. Hence breeding methods like heterosis and population breeding has to be followed to develop early genotypes. Similar result was reported by Cill and Randhawa, 1975.

Heritability estimates of the 78 genotypes revealed that high heritability coupled with high genetic advance as per cent of mean for most of the characters was observed indicating the presence of considerable genetic variation and additive gene effects. Hence, the improvement of these characters could be effective through phenotypic selection.

In the current study, high heritability coupled with high genetic advance as per cent of mean were recorded for flowering, for maturity, number of panicles, panicle length, panicle breadth, panicle weight, test weight and grain yield in both the seasons. This indicates that there was low environmental influence on the expression of these characters. Since these traits are controlled by additive gene action they can be exploited by pure line selection and mass selection methods. High heritability and high genetic advance as per cent of mean are reported by Sandhu et al.(1974) Nagarajan and Prasad (1980), Chidambaram and Palanisamy, (1995), Nirmalakumari and Vetriventhan (2010), Prasanna et al.(2013) for days to flowering number of tillers, panicle length, Panicle weight, test weight, straw weight and grain yield.

High heritability coupled with moderate genetic advance observed for days to maturity, plant height and panicle breadth in both the seasons. This can be exploited by mass selection, progeny selection, hybridization and simple selection for additive gene action and heterosis breeding for non additive gene action. Similarly Nirmalakumari and Vetriventhan (2010) reported high heritability with low genetic advance for plant height whereas, Prasanna et al. (2013) reported for panicle breadth.

The present investigation revealed high heritability coupled with high genetic advance as per cent of mean was observed for most of the characters. This indicates the presence of considerable genetic variation and additive gene effects for the characters. Hence, improvement of these characters could be effective through phenotypic selection.

\section{Conclusion}

The analysis of variance revealed the presence of highly significant differences in germplasm collections for all the characters under study for morphological traits indicating presence of genetic variability for most of the traits. High values of PCV and GCV were obtained for grain yield per plot and straw yield per plant and moderate estimates for panicle length, panicle weight and test weight and low estimates for plant height, panicle breadth. This indicates the existence of comparatively high variability for these traits, which could be exploited for improvement of the traits through selection in advanced generations.

Days to flowering, days to maturity, number of tillers per plant, panicle weight, test weight and grain yield in both the seasons exhibited higher heritability coupled with high genetic advance as per cent of mean. This indicates the scope of selection in the population, since there is a wide range of variation and additive gene action.

\section{References}

[1]. Jiayju, C., 1986, Small Millet in Global Agriculture. Oxford and IBH Publishing company private Limited.

[2]. Burton G W. 1952. Quantitative inheritance in grasses. Proc., 6th International Grassland Congress 1: $277-283$.

[3]. Cill, A.S., and A.S. Randhawa. 1975. Heritable variation and interrelationship in foxtail millet (Setaria italica (L.) P. Beauv.). Madras Agric. J., 62(5): 253 -258.

[4]. Chidambaram, S. and Palanisamy, 1995, Variability and correlation studies of dry matter with reference to selection criteria in foxtail millet (Setaria italica) Madras Agril. J., 82(1): 1- 3.

[5]. Dabholkar, A.R. 1999. Elements of biometrical genetics. Revised and enlarged edition. Published and printed by Concept Publishing Company, New Delhi.

[6]. Islam, M. H., Mannujan and Saker, S., 1990, Genetic evaluation of foxtail millet. Pakistan J. Agric. Res., 11 (2): 89-92.

[7]. Johnson, H. W., Robinson, H. F. and Comstock, H. F., 1955, Estimates of genetic and environmental variability in soybean. Agron. J., 47: 314-318.

[8]. Lakshmanan, D. and A.K. Guggeri. 2001. Genetic variaiblity studies in foxtail millet. Karnataka J. Agril. Sci. 14(2) : 311-314.

[9]. Nagarajan K and Prasad M N 1980 Studies on genetic diversity in foxtail millet (Setaria italica (L.) Beauv). Madras Agril. J., 67 (1): 28-38.

[10]. Nirmalakumari, A. and Vetriventhan M., 2010, Characterization of foxtail millet germplasm collections for yield contributing traits. Electronic J. Plant Breed., 1 (2) : 140 -147.

[11]. Nirmalakumari, A., G. Ganapathy and R. Murugan, 2008, Studies on variability and descriptive statistics in foxtail millet germplasm. Crop Res., $\quad$ 35 $80-82$. 
[12]. Prasanna, Samba Murthy, J. S. V., Rama Kumar, P. V. and Srinivasa Rao, V., 2013, Nature of gene action for yield and yield components in exotic genotypes of Italian millet [Setaria italica (L.) Beauv]. J. Plant Breed. Crop Sci., 5 (5) : 80-84.

[13]. Reddy, C. V. C. M. and Reddy, P. V. R. M. 2012, Genetic variability for biometrical traits in foxtail millet .Plant Archives., 12 (2) : 753-755.

[14]. Sandhu, T. S., Arora, B. S. and Yashvir Singh, 1974, Interrelationships between yield and yield components in foxtail millet. Indian J. Agril. Sci., 44 (9):563- 566.

[15]. Selvarani, M. and Gomathinayagam, S.P., 2000b. Genetic variability in foxtail millet [Setaria italica (L.) Beauv.]. Crop Res., 20(3) : 553-554.

Table 1: Estimates of mean, variability, heritability and genetic advance as per cent of mean in foxtail millet during rainy season 2013

\begin{tabular}{|c|c|c|c|c|c|c|c|c|c|}
\hline \multirow{2}{*}{$\begin{array}{l}\text { Sl. } \\
\text { No. }\end{array}$} & \multirow{2}{*}{ Characters } & \multirow{2}{*}{ Mean } & \multicolumn{2}{|c|}{ Range } & \multirow{2}{*}{$\begin{array}{c}\text { GCV } \\
(\%)\end{array}$} & \multirow{2}{*}{$\begin{array}{c}\text { PCV } \\
(\%)\end{array}$} & \multirow{2}{*}{$\begin{array}{l}h^{2} \mathbf{b s} \\
(\%)\end{array}$} & \multirow{2}{*}{ GA } & \multirow{2}{*}{$\begin{array}{c}\text { GA as per } \\
\text { cent of } \\
\text { mean } \\
\end{array}$} \\
\hline & & & Minimum & Maximum & & & & & \\
\hline 1. & Days to flowering & 45.47 & 31.33 & 93.95 & 12.42 & 12.52 & 98.4 & 11.54 & 25.38 \\
\hline 2. & Days to maturity & 90.13 & 61.67 & 104.00 & 9.27 & 10.05 & 85.2 & 15.89 & $17 . .64$ \\
\hline 3. & Plant height $(\mathrm{cm})$ & 122.97 & 67.95 & 138.37 & 7.66 & 8.25 & 85.8 & 17.93 & 14.58 \\
\hline 4. & Number of tillers per plant & 10.87 & 5.07 & 15.73 & 18.15 & 21.91 & 68.7 & 3.36 & 31.03 \\
\hline 5. & Panicle length $(\mathrm{cm})$ & 20.21 & 7.58 & 28.86 & 12.57 & 15.45 & 66.2 & 4.24 & 21.08 \\
\hline 6. & Panicle breadth $(\mathrm{cm})$ & 6.53 & 4.56 & 9.15 & 8.09 & 9.41 & 73.9 & 0.93 & 14.32 \\
\hline 7. & Panicle weight per plant $(\mathrm{g})$ & 44.41 & 22.94 & 75.10 & 16.36 & 17.02 & 92.4 & 210.80 & 32.38 \\
\hline 8. & Grain yield per plant $(\mathrm{g})$ & 34.42 & 11.20 & 47.57 & 21.89 & 23.23 & 88.8 & 70.36 & 42.49 \\
\hline 9. & Grain yield per plot (g) & 240.42 & 184.58 & 559.99 & 19.99 & 20.41 & 95.9 & 230.12 & 40.32 \\
\hline 10. & Test weight $(\mathrm{g})$ & 3.16 & 2.23 & 3.89 & 12.88 & 13.21 & 95.1 & 0.81 & 25.88 \\
\hline 11. & Straw weight per plant(g) & 67.52 & 31.02 & 276.34 & 21.66 & 41.65 & 97.0 & 15.66 & 23.20 \\
\hline
\end{tabular}

Table 2: Estimates of mean, variability, heritability and genetic advance as per cent of mean in foxtail millet during post rainy season 2014

\begin{tabular}{|c|c|c|c|c|c|c|c|c|c|}
\hline \multirow{2}{*}{$\begin{array}{l}\text { Sl. } \\
\text { No. }\end{array}$} & \multirow{2}{*}{ Characters } & \multirow{2}{*}{ Mean } & \multicolumn{2}{|c|}{ Range } & \multirow{2}{*}{$\begin{array}{l}\text { GCV } \\
(\%)\end{array}$} & \multirow{2}{*}{$\begin{array}{r}\text { PCV } \\
(\%)\end{array}$} & \multirow{2}{*}{$\begin{array}{l}\mathbf{h}^{2} \mathbf{b s} \\
(\%)\end{array}$} & \multirow{2}{*}{ GA@5\% } & \multirow{2}{*}{$\begin{array}{c}\text { GA as per } \\
\text { cent of } \\
\text { mean@5\% }\end{array}$} \\
\hline & & & Minimum & Maximum & & & & & \\
\hline 1. & Days to flowering & 47.03 & 33.33 & 58.00 & 12.25 & 12.36 & 98.20 & 11.62 & 25.01 \\
\hline 2. & Days to maturity & 89.23 & 60.67 & 103.00 & 9.27 & 10.06 & 84.90 & 15.69 & 17.59 \\
\hline 3. & Plant height $(\mathrm{cm})$ & 157.10 & 120.03 & 177.60 & 5.41 & 6.69 & 65.40 & 14.16 & 9.02 \\
\hline 4. & Number of tillers per plant & 25.72 & 16.83 & 41.83 & 20.18 & 21.06 & 91.80 & 10.25 & 39.84 \\
\hline 5. & Panicle length $(\mathrm{cm})$ & 20.55 & 14.33 & 32.53 & 14.61 & 15.51 & 93.40 & 5.98 & 29.09 \\
\hline 6. & Panicle breadth $(\mathrm{cm})$ & 5.96 & 4.58 & 7.69 & 8.81 & 9.31 & 89.50 & 1.02 & 17.67 \\
\hline 7. & $\begin{array}{r}\text { Panicle weight per } \\
\text { plant }(\mathrm{g})\end{array}$ & 132.35 & 35.47 & 183.43 & 17.85 & 19.77 & 81.50 & 43.94 & 13.20 \\
\hline 8. & Grain yield per plant $(\mathrm{g})$ & 104.07 & 23.59 & 148.33 & 20.72 & 21.93 & 89.30 & 41.97 & 14.33 \\
\hline 9. & Grain yield per plot $(\mathrm{g})$ & 846.44 & 437.45 & 1354.05 & 22.29 & 23.06 & 93.40 & 375.73 & 44.39 \\
\hline 10. & Test weight(g) & 3.00 & 2.08 & 3.87 & 13.48 & 13.82 & 95.00 & 0.83 & 27.06 \\
\hline 11. & Straw weight per plant(g) & 215.48 & 49.84 & 300.18 & 23.33 & 23.86 & 95.60 & 101.25 & 46.99 \\
\hline
\end{tabular}

